Provided for non-commercial research and education use. Not for reproduction, distribution or commercial use.

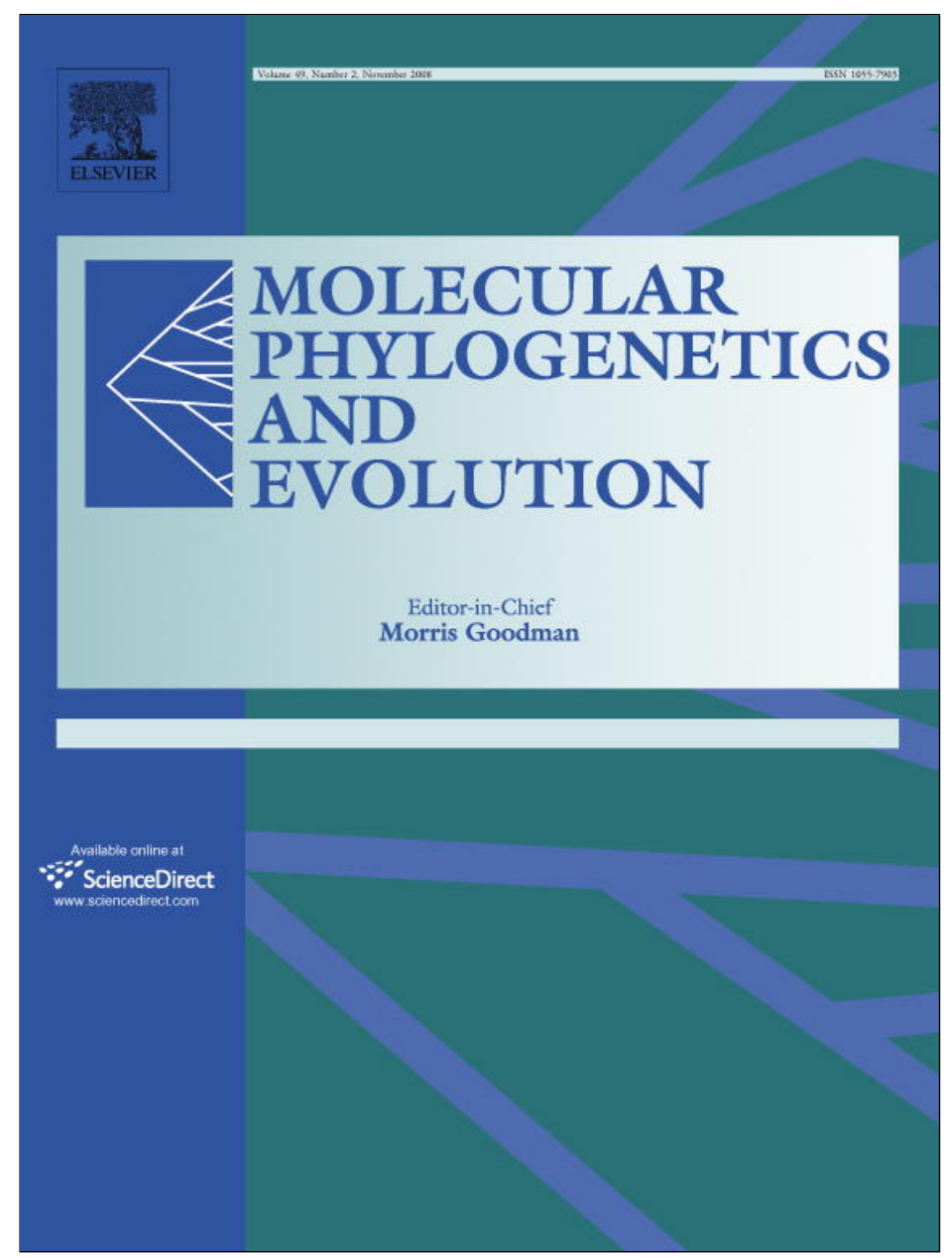

This article appeared in a journal published by Elsevier. The attached copy is furnished to the author for internal non-commercial research and education use, including for instruction at the authors institution and sharing with colleagues.

Other uses, including reproduction and distribution, or selling or licensing copies, or posting to personal, institutional or third party websites are prohibited.

In most cases authors are permitted to post their version of the article (e.g. in Word or Tex form) to their personal website or institutional repository. Authors requiring further information regarding Elsevier's archiving and manuscript policies are encouraged to visit:

http://www.elsevier.com/copyright 


\title{
Evidence of a highly complex phylogeographic structure on a specialist river bird species, the dipper (Cinclus cinclus)
}

\author{
F. Hourlay ${ }^{\mathrm{a}, *}$, R. Libois ${ }^{\mathrm{a}}$, F. D’Amico ${ }^{\mathrm{b}}$, M. Sarà ${ }^{\mathrm{c}}$, J. O’Halloran $^{\mathrm{d}}$, J.R. Michaux ${ }^{\mathrm{e}, \mathrm{f}}$ \\ ${ }^{a}$ Zoogeography Researchs Unit, Institut de Botanique, Université de Liège, 4000 Liège, Belgium \\ b University of Pau and Pays de l'Adour, UMR 1224 ECOBIOP UPPA-INRA avenue de l'Universite, BP1155, F-64013 Pau Cedex, France \\ ' Università degli Studi di Palermo, Dipartimento di Biologia Animale, “G. Riverberi”, Via Archirafi, 18-90123 Palermo, Italy \\ ${ }^{\mathrm{d}}$ Department of Zoology, Ecology, Plant Science, Environmental Research Institute, University College Cork, Ireland \\ ${ }^{\mathrm{e}}$ Laboratoire de génétique des microorganismes, Institut de Botanique, Université de Liège, 4000 Liège, Belgium \\ ${ }^{\mathrm{f}}$ Centre de Biologie et de Gestion des Populations (CBGP), UMR 1062, Campus international de Baillarguet, CS 30016, 34988 Montferrier/Lez, France
}

\section{A R T I C L E I N F O}

\section{Article history:}

Received 7 September 2007

Revised 5 June 2008

Accepted 30 July 2008

Available online 14 August 2008

\section{Keywords:}

Cinclus cinclus

Phylogeography

Glacial refuges

Quaternary glaciations

Mitochondrial DNA

Taxonomy

\begin{abstract}
A B S T R A C T
This study details the phylogeographic pattern of the white-throated dipper (Cinclus cinclus), a Palearctic, temperate, passerine bird that is exclusively associated with flowing water. Our results reveal a complex phylogeographic structure with at least five distinct lineages for the Western Palearctic region. As for many species of the Western Palearctic fauna and flora, this genetic structure is probably linked to the isolation of populations in different southern refuges during glacial periods. Furthermore, the isolation of populations in Scandinavia and/or Eastern regions, but also in Morocco and probably in Corsica, was accentuated by ecological and biogeographic barriers during Quaternary interglacial periods. During glacial periods, Italy, Sicily and the Balkano-Carpathian region acted as major refuge zones for the dipper. At the end of the last ice age, Western Europe was repopulated by dippers from an Italian refuge, while Eastern Europe was recolonised by Balkano-Carpathian birds. A large contact zone between these two lineages was evidenced and extends from Luxembourg to Hungary. Finally, our results indicate the need to clarify the taxonomic status of the dipper, especially concerning the European subspecies whose validity appears uncertain.
\end{abstract}

(c) 2008 Elsevier Inc. All rights reserved.

\section{Introduction}

The last 700,000 years of the Quaternary were characterised by a succession of glacial and interglacial periods, with a tempo of $\pm 100,000$ years (Webb and Bartlein, 1992). Major changes occurred in the composition and location of European biotas as a response to these climatic fluctuations (Comes and Kadereit, 1998).

During glacial periods, temperate species could only survive in suitable habitats, mainly located in southern areas. Evidence from fossil and pollen data suggests that three main glacial refuges for temperate species were located in the southern peninsulas of Iberia, Italy, and the Balkans (Bennett et al., 1991; Hewitt, 1996; Blondel, 1997). More recently, other areas located near the Caucasus, the borders of the Black Sea and in the Carpathian region were also identified as potential glacial refuges (Hewitt, 2004; Deffontaine et al., 2005).

As the ice cover retreated during interglacial periods, refuge populations expanded northwards, colonizing new ice-free regions (Taberlet et al., 1998). These contractions and expansions in the

\footnotetext{
* Corresponding author. Fax: +32 43663847.

E-mail address: Frederic.Hourlay@student.ulg.ac.be (F. Hourlay).
}

ranges of temperate species have left signatures in both the geographical distribution and the genetic diversity of extant populations (Bennett et al., 1991; Hewitt, 1996; Avise, 2000).

When compared to other taxa, birds present an enigma regarding postulated levels of geographical structure and magnitude of gene flow (Avise, 2000). On one hand, their generally high dispersal capacities should prevent the appearance of strong genetic structures, but on the other hand, many species show a strong philopatry (Newton, 1998). This generates obvious geographical differences between conspecific populations. Phylogeographic studies conducted on a growing number of bird species in the world have uncovered a great variety of mtDNA patterns (Zink, 1997; Avise, 2000). However, in Europe, with the exception of a few large studies (Griswold and Baker, 2002; Brito, 2005), most phylogeographic studies concerning birds have been restricted to subsets of the three main putative refuges, due to restricted sampling, or to constraints in species range (Brito, 2005). Results of these studies are contradictory. (i) Some species did not show any clear phylogeographic structure (Seutin et al., 1995; Questiau et al., 1999; Zink et al.,2002a,b; Koopman et al., 2005). Several reasons might be evoked to account for this: restricted sample and/or the use of molecular markers with insufficient sensitivity (Crochet 
et al., 2000), recent recolonisation events (Gay et al., 2004) and erratic behaviour (Questiau et al., 1999; Koopman et al., 2005). (ii) In contrast, other birds displayed phylogeographic patterns congruent with the Mediterranean refuges hypothesis (Griswold and Baker, 2002; Liukkonen-Anttila et al., 2002; Kvist et al., 2004; Brito, 2005). (iii) Finally, Nordic and/or marine species displayed distinct patterns with refuges located more northward (Tiedemann et al., 2004; Ruokonen et al., 2005) and/or close to the Atlantic Ocean, the Mediterranean and Black Sea (Kidd and Friesen, 1998; Liebers et al., 2001; Moum and Arnason, 2001).

The white-throated dipper has a very large and fragmented distribution across Europe, Asia and North Africa (Fig. 1) (Cramp, 1988; Hagemeijer and Blair, 1997). The representatives of this family (Cinclidae) are exclusively riverine, being entirely restricted to fast flowing rivers and streams, and their diet is almost exclusively comprised of benthic macro-invertebrates (Tyler and Ormerod, 1994; D’Amico and Hémery, 2007). An important clinal variation concerning body size and plumage colors has been described for the white-throated dipper. This has led to the description of many subspecies whose validity is often questionable, as such subspecies are not always geographically isolated, nor morphologically well defined (Tyler and Ormerod, 1994). Ten out of the 13 recognized subspecies (Cramp, 1988) are present within the Western Palaearctic region, and other three occur in the eastern Palearctic. Whitethroated dippers are generally sedentary monogamous birds. Limited dispersion movements observed for this species (Tyler and Ormerod, 1994; O'Halloran et al., 2000) probably strongly limit gene flow between populations. All these characteristics make this bird a particularly interesting model for a phylogeogaphic study. A first study conducted by Lauga et al. (2005) on this species concluded to a lack of a phylogeographic pattern, highlighting the need to reconsider the intraspecific taxonomy of such a species.

The present study aims to clarify the phylogeographic patterns of white-throated dippers in the Western Palearctic, using a larger

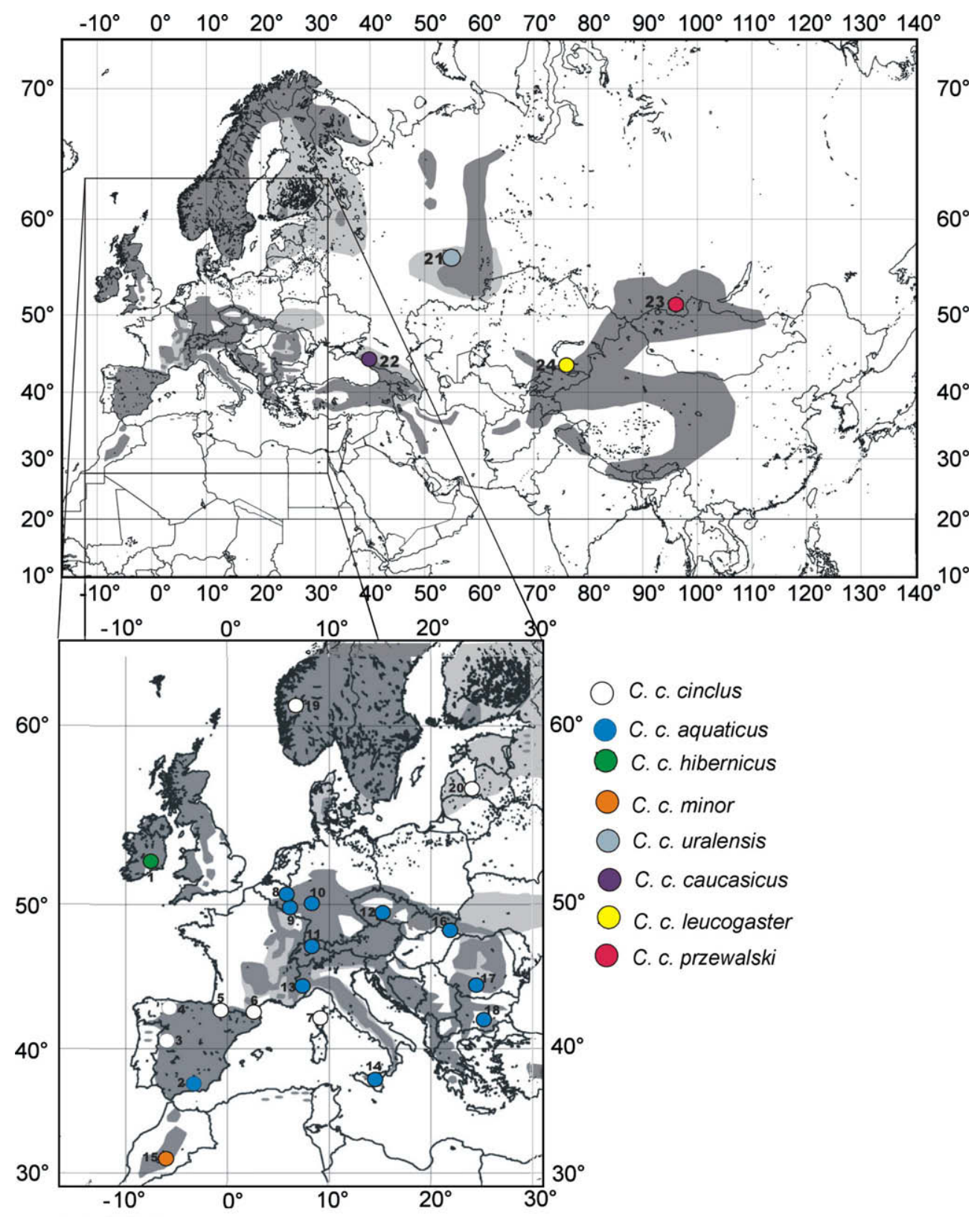

Fig. 1. Geographical distribution of Cinclus cinclus samples, symbols colors refer to the different subspecies as described by Cramp (1988) (see Appendix 1 for samples characterisation). Dark grey zones correspond to the breeding range distribution of the dipper; light grey zones correspond to wintering zones. 
number of populations spread throughout the entire region and based on the analysis of three molecular markers. This study will help to determine whether a bird species that is strongly associated with fast flowing waters, and more adapted to cold conditions, reacted to the Quaternary climate changes in the same way as other temperate bird species. More specifically, this study aims to answer the following questions: (i) Is the white-throated dipper genetically heterogeneous? If so, is this heterogeneity geographically structured? (ii) How did the Quaternary climatic oscillations affect the distribution of this species? (iii) In which regions did the dipper survive during the Quaternary ice age? (iv) How did the dipper recolonise Europe after the last pleniglacial?

Answers to these questions will provide a new insight into the intraspecific taxonomy of dippers, allowing a reconsideration of the validity of some of the numerous current subspecies.

\section{Materials and methods}

\subsection{Sample collection}

Hundred and six tissue samples from white-throated dippers were obtained from 24 populations located mostly in the Western Palearctic and representing 8 of the 13 formerly described subspecies (Cramp, 1988) (Fig. 1, Appendix 1). Tissue samples from eastward uralensis, caucasicus, leucogaster and przewalski subspecies were provided by the Burke Museum (Washington, USA) (Museum numbers: UWBM 46430, 61537, 64752, 64772, 70974 and 71403). Cinclus mexicanus and Cinclus pallasii were used as outgroups for our study (Museum numbers: UWBM 46768 and 51144) according to previous phylogenetic studies performed on this genus (Voelker, 2002).

With the exception of the samples provided by the Burke Museum, tissue samples consisted of 20-100 $\mu \mathrm{l}$ of blood, collected under licence by puncturing the brachial or tarsal vein. Blood was immediately placed in an APS Buffer (Arctander, 1988) and frozen at $-20^{\circ} \mathrm{C}$ for long-term conservation. Individuals were quickly released in the wild after blood samplings.

\subsection{DNA extraction and amplification}

Total DNA was extracted using the Qiagen DNeasy Tissue Kit (cat. no. 69506) following the manufacturer instructions.

We amplified 3 fragments of the mitochondrial genome, including the cytochrome $b$ gene, the ND2 gene and domains II and III of the control region (CR). Total length of the amplified fragments is equal to $3096 \mathrm{bp}$. Each $50 \mu \mathrm{l}$ polymerase chain reaction (PCR) contained \pm 50 ng of total DNA, $350 \mathrm{mM}$ of each dNTP, 0.5 pmol of each primer, 2 units DNA polymerase and a final concentration of $1.5 \mathrm{mM} \mathrm{MgCl}{ }_{2}$.
The primers used for amplification and sequencing are listed in Table 1. Amplification protocol for the cytochrome $b$ gene (length $=1079 \mathrm{bp}$ ) consisted in 40 cycles of $30 \mathrm{~s}$ at $94^{\circ} \mathrm{C}$ (denaturation step), $30 \mathrm{~s}$ at $49.5^{\circ} \mathrm{C}$ (annealing step) and $75 \mathrm{~s}$ at $72{ }^{\circ} \mathrm{C}$ (elongation step). Protocols were identical for the ND2 gene (length $=1085 \mathrm{bp}$ ) and the control region (length $=932 \mathrm{bp}$ ), except for the annealing temperature that was respectively equal to $55^{\circ} \mathrm{C}$ (ND2) and $59^{\circ} \mathrm{C}(\mathrm{CR})$. Both strands of these mitochondrial regions were sequenced using automated sequencers from the Macrogen society (Seoul, Korea).

\subsection{Sequence analyses}

The sequences were aligned using the ED editor of the MUST package (Philippe, 1993). A combined matrix for the control region (926 bp), ND2 (1075 bp) and cytochrome $b$ (1079 bp) sequences was used to determine the phylogeographic structure of the dipper.

Networks were constructed using the minimum spanning network method (MINSPNET in ARLEQUIN 2.0, Schneider et al., 2000), statistical parsimony (TCS, Clement et al., 2000) and median-joining network (Bandelt et al., 1999; Network 4.000 available at www.fluxus-engineering.com). Phylogenetic reconstructions were also performed using neighbour joining (NJ; Saitou and Nei, 1987) and maximum parsimony (MP; Fitch, 1971) algorithms implemented in PAUP 4.0b8 (Swofford, 2000), as well as the maximum likelihood algorithm (ML; Felsenstein, 1981) implemented in the PHYML program (Guindon and Gascuel, 2003). Phylogenetic trees were rooted by sequences from $C$. mexicanus and $C$. pallasii. $\mathrm{NJ}$ and ML analyses were performed using the $\mathrm{HKY}+\mathrm{I}+\mathrm{G}$ model (Hasegawa et al., 1985; Yang, 1993; Gu et al., 1995) suggested for the data by MODELTEST 3.0 (Posada and Crandall, 1998) with a gamma distribution shape parameter of $\alpha=0.9684$ (Yang, 1996) and a proportion of invariable sites of $I=0.5224$. The robustness of the nodes on the trees was assessed by bootstrap re-sampling (BP; Felsenstein, 1985) with 1000 random repetitions for MP, NJ and ML analysis.

\subsubsection{Genetic structure and demographic trends}

An analysis of molecular variance (AMOVA) was performed using the ARLEQUIN 2.0 program to examine hierarchical population genetic structure (Schneider et al., 2000). Analyses were performed on 20 populations within six groups, these groups reflecting the geographic distribution of the studied animals.

Haplotype $(h)$ and nucleotide $(\pi)(\mathrm{Nei}, 1987)$ diversities and their standard deviations (Tajima, 1993) were estimated using the DNASP 4.0. software (Rozas et al., 2003).

A mismatch distribution analysis was also performed to investigate indications of demographic expansions using DNASP 4.0. We examined the 'raggedness' value ( $\mathrm{Rg}$ ) and the sum of squared

Table 1

List of primers used for amplification and sequencing

\begin{tabular}{|c|c|c|c|c|}
\hline Primer name & Sequence & Amplification & Sequencing & Source \\
\hline \multicolumn{5}{|l|}{ Control region } \\
\hline H450rev & 5'-ATG-CCA-CTG-GTT-CCT-ATT-TC-3' & $\mathrm{X}$ & $\mathrm{X}$ & Present study \\
\hline CINDW & 5'-TGT-ATG-ACC-GCG-GTG-GCT-GG-3' & $\mathrm{X}$ & $\mathrm{X}$ & Present study \\
\hline \multicolumn{5}{|l|}{ ND2 } \\
\hline L5215 & 5'-TAT-CGG-GCC-CAT-ACC-CCG-AAA-AT-3' & $\mathrm{X}$ & $\mathrm{X}$ & Hackett (1996) \\
\hline H6313 & 5'-CTC-TTA-TTT-AAG-GCT-TTG-AAG-GC-3' & $\mathrm{X}$ & $\mathrm{X}$ & Johnson and Sorenson (1998) \\
\hline L5578 & 5'- TCT-GAT-TCC-CAG-AAG-TAC-TAC-AAG-G-3' & & $\mathrm{X}$ & Voelker (2002) \\
\hline L5758 & 5'-GGG-TGA-ACG-GGC-CTA-AAC-CAA-AC- $3^{\prime}$ & & $\mathrm{X}$ & Voelker (2002) \\
\hline \multicolumn{5}{|l|}{ Cyt. $b$} \\
\hline L14841 & 5'-AAA-AAG-CTT-CCA-TCC-AAC-ATC-TCA-GCA-TGA-TGA-AA-3' & $\mathrm{X}$ & $\mathrm{X}$ & Kocher et al. (1989) \\
\hline H16065 & 5'-GGA-GTC-TTC-AGT-CTC-TGG-TTT-ACA-AGA-C-3' & $\mathrm{X}$ & $\mathrm{X}$ & Helm-Bychowski and Cracraft (1993) \\
\hline L15383 & 5'-GGA-CAA-ACA-CTA-GTA-GAA-TG-3' & & $\mathrm{X}$ & Pasquet et al. (1999) \\
\hline
\end{tabular}


deviation (SSD) to assess the statistical significance of the distribution within ARLEQUIN 2.000 (Schneider et al., 2000) under the rapid expansion model.

Expansion times $\left(t_{\mathrm{e}}\right)$ were estimated using the relationship between $t_{\mathrm{e}}$ and Tau $(\tau)$ (Rogers and Harpending, 1992). We also calculated Fu's Fs value (Fu, 1997) as an indicator of demographic expansion. All these values were calculated using DNASP 4.0.

\subsubsection{Divergence time analyses}

The genetic distance (\%-Kimura 2 parameters, $\mathrm{K}_{2} \mathrm{P}$ ) between lineages was obtained using the MEGA 2.1 program (Kumar et al., 2001). Where necessary, $K_{2} P$ distances were corrected for ancestral mtDNA polymorphism using Edwards and Beerli formula (2000). Since we found no listed fossils of white-throated dipper (Mourer-Chauviré, 1995; Bochenski, 1997), we referred to Voelker's (2002) paper on the phylogeny of Cinclidae to have a calibration point in order to estimate divergence times between the different lineages of White-throated dipper. According to Voelker, the separation event between Cinclus cinclus and C. pallasii should have occured about $2.54 \mathrm{Myr}$ ago. This approach can give only a rough estimation of the separation times between the different lineages, especially when such times are rather recent; indeed, Ho et al. (2005) clearly showed the danger of overestimation for the recent dates of separation when calibration points are too ancient. Nevertheless, we performed the calculation as it was the only possibility to have an estimation of the chronology of appearance of the different $C$. cinclus lineages.

\section{Results}

\subsection{Sequence variation}

The three studied genes were weakly variable $(28,30$ and 63 variable sites and 16, 24 and 22 parsimony informative sites for the control region, ND2 and cytochrome $b$ genes, respectively). Therefore, the phylogenetic reconstructions performed on these genetic markers taken independently, gave important polytomies with weak genetic structures among dipper populations. According to these results, we preferred to concatenate our markers to improve our topologies.

Using this combined data matrix, a total of 51 haplotypes were identified among the 106 white-throated dippers. Out of the 3096 bp sequenced, 205 sites were variable and 158 were parsimony informative. The average values of transitions to transversions ratio is equal to 4.6110 , and base composition is: T $23.7 \%, \mathrm{C}$ $32 \%$, A $31 \%$ and G $13.3 \%$.

\subsection{Phylogenetic analyses}

The minimum spanning network (Fig. 2) shows the existence of several lineages that are well differentiated from a genetical and a geographical point of view:

- A large West European lineage, including specimens from Italy, Spain, France (except Corsica), Switzerland, Belgium, Germany, Czech Republic, Hungary and Ireland;

- an East European lineage, including Bulgarian and Romanian populations as well as some animals from Hungary, Czech republic, Germany and Luxembourg;

- a North-East European lineage (birds from Norway, Latvia, Ural);

- a lineage including Moroccan dippers;

- another lineage including Caucasian birds;

- finally a 'miscellaneous' group including an isolated animal from Ireland, another isolated animal from Corsica, and the 2 asiatic birds.
A minimum of four mutational steps separate these lineages from each other, with the Asiatic birds being the most distant and separated from the rest of the sample by a minimum of 26 mutational steps.

Within the West European lineage, almost all of the haplotypes are connected in a large star-like topology. The central haplotype of such a topology corresponds to a large number of animals (30) coming from various geographical origins. Nonetheless, some geographical structuration, with North Italian, Andalusian, Sicilian and Irish subgroups, seems to appear within the lineage.

Other network methods (statistical parsimony and medianjoining network) give the same topology. Phylogenetic reconstructions performed using maximum parsimony algorithms, neighbour-joining and maximum likelihood methods (not shown here) confirm these results: the composition of major lineages is identical to those formed by the minimum spanning network (with a high bootstrap support ranging from $73 \%$ to $100 \%$ ), with the only exception of the isolated animal from Ireland which is included in the North-East European lineage.

\subsection{Population structure and genetic diversities}

\subsubsection{Partitioning of genetic variation and gene flow}

The AMOVA analysis (Table 2) shows that the mtDNA variation observed in our samples is almost equally distributed among groups (43.04\%) and among populations within groups (40.86\%). This indicates a substantial genetic structure among the six groups we have defined, but also among the populations that constitute these groups. In contrast, mtDNA variation within populations was much lower (16.10\%).

\subsubsection{Genetic structure and demographic trends}

To test the Mediterranean refugia hypothesis and to locate potential glacial refuges for the dipper, nucleotide and haplotype diversities were calculated for the different lineages and populations from these lineages (see Table 3 for results and grouping characterisation). In spite of the important size of sequences obtained, dippers display low levels of nucleotide diversity, ranging from 0.00018 (Ireland) to 0.00132 (Sicily).

Within the West European lineage, the Sicilian population displays significantly higher nucleotide diversity than the North Italian population. These 2 populations display significantly higher nucleotide diversities than all the other populations, while the Irish population displays significantly the lowest nucleotide diversity values ( $\pi=0.00018 \pm 0.00004$ ) as compared to the other populations. The same schema was observed for haplotype diversity values. However, although the Sicilian population has the highest haplotype diversity value ( $h=0.900 \pm 0.161$ ), no significant difference is observed between this population and the North Italian, Spanish and Central West European populations $(p>0.05)$.

Within the East European lineage, the Balkano-Carpathian population (Romanian and Bulgarian birds) displays significantly higher nucleotide diversity value (but not haplotype diversity value) as compared to the Central East European population (comprising animals from Hungary, Czech Republic, Germany and Luxembourg).

Although the sampling for some of the populations could appear too low to make these statements, we performed mismatch distribution analyses on populations living in the geographic areas considered as potential refuges in Europe (see Michaux et al.1998; Carlsson, 2003; Randi et al. 2003; Hewitt 2004) (Fig. 3). These analyses indicate that the Spanish and Northern Italian populations are characterised by a signal of population in expansion, whereas the Sicilian and Balkano-Carpathian populations show a more heterogeneous mismatch distribution that could suggest long term stabil- 


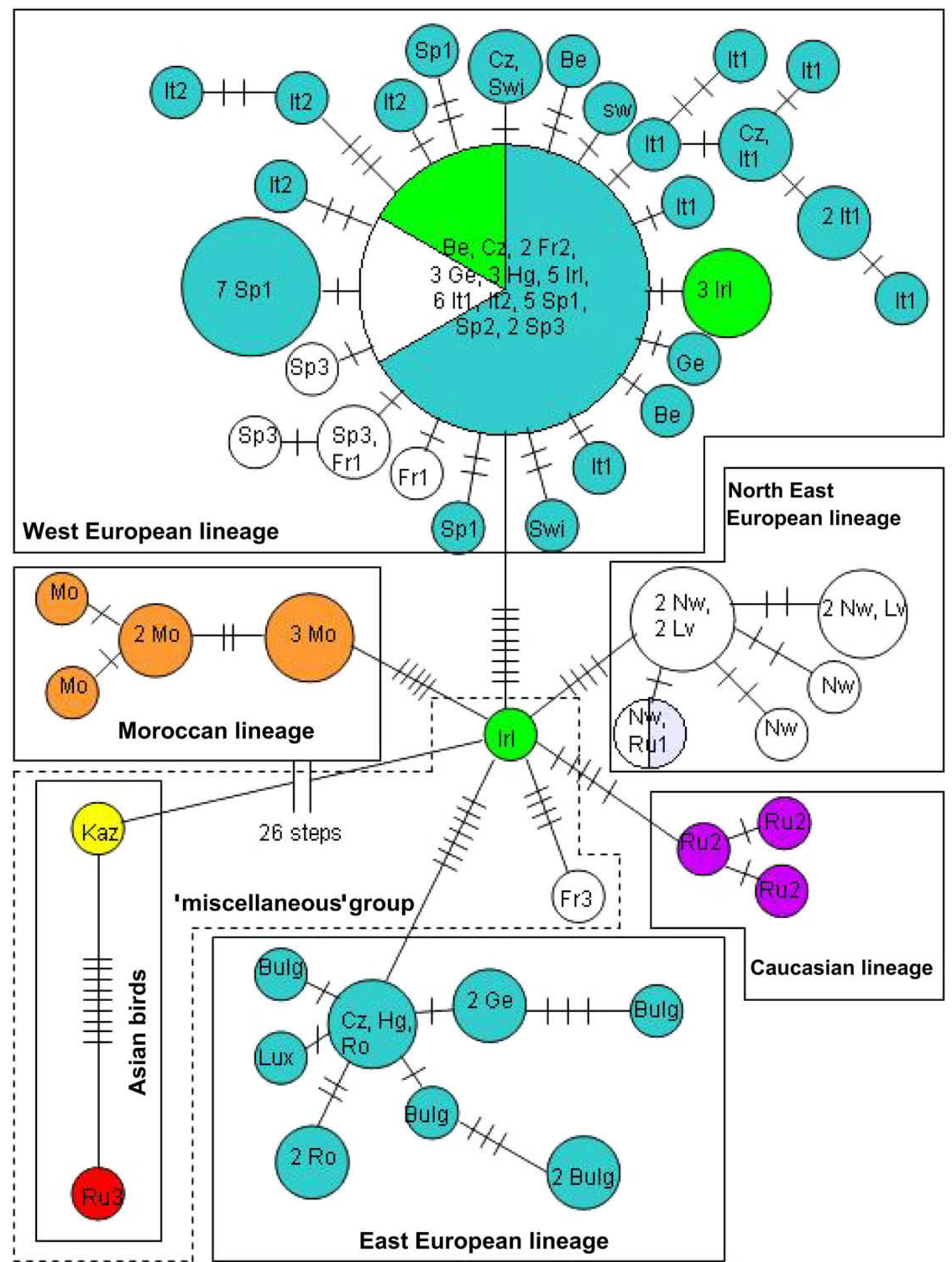

Fig. 2. Minimum spanning tree of the White-throated dipper. Area of circles is proportional to the number of individuals sharing that haplotype. Text inside circles includes number of individuals (if $>1$ ) and sampling location-geographical abbreviations correspond to countries listed in the Appendix 1 . Subspecies occurrence is shown by different kinds of colors (see Fig. 1).

Table 2

Hierarchical AMOVA computed with the twenty populations of dippers distributed in six groups (statistical significance: $p<0.0001$ )

\begin{tabular}{lrcc}
\hline Source of variation & d.f. & Sum of squares & Variance components \\
\hline Among groups & 5 & 130.423 & 1.55752 \\
Among populations within groups & 14 & 118.137 & 1.47865 \\
Within populations & 86 & 50.090 & 0.58245 \\
Total & 105 & 298.651 & 3.61862 \\
\hline
\end{tabular}


Table 3

Nucleotide diversity $(\pi)$ and haplotype diversity $(h)$ of the White-throated dipper lineages and populations

\begin{tabular}{|c|c|c|c|c|c|c|}
\hline Lineages and populations & Sample size & Haplotypes & Nucleotide diversity $(\pi)$ & Standard deviation & Haplotype diversity $(h)$ & Standard deviation \\
\hline Total & 106 & 51 & 0.00269 & 0.00029 & 0.901 & 0.025 \\
\hline Western Europe & 68 & 27 & 0.00054 & 0.00007 & 0.769 & 0.053 \\
\hline North Italy & 15 & 9 & 0.00062 & 0.00012 & 0.838 & 0.085 \\
\hline Sicily & 5 & 5 & 0.00132 & 0.00034 & 0.900 & 0.161 \\
\hline Spain & 24 & 8 & 0.00043 & 0.00008 & 0.757 & 0.066 \\
\hline Ireland & 8 & 2 & 0.00018 & 0.00004 & 0.536 & 0.123 \\
\hline Corsica & 1 & 1 & - & - & - & - \\
\hline Central West Europe & 16 & 8 & 0.00047 & 0.00012 & 0.758 & 0.11 \\
\hline Eastern Europe & 13 & 8 & 0.00097 & 0.00018 & 0.923 & 0.050 \\
\hline Balkano-Carpathian & 8 & 6 & 0.00126 & 0.00021 & 0.929 & 0.084 \\
\hline Central East Europe & 5 & 3 & 0.00033 & 0.00009 & 0.800 & 0.164 \\
\hline North East Europe & 12 & 6 & 0.00075 & 0.00015 & 0.848 & 0.074 \\
\hline Morocco & 7 & 4 & 0.00057 & 0.00011 & 0.810 & 0.130 \\
\hline Caucasus & 3 & 3 & 0.00043 & 0.00014 & 1.000 & 0.272 \\
\hline Asia & 2 & 2 & 0.00292 & 0.00146 & 1.000 & 0.500 \\
\hline
\end{tabular}

Spain population includes birds from Spain and from the French Pyrenees; Central West Europe population includes birds from Belgium, Germany, Switzerland, Czech Republic and Hungary belonging to the Western Europe lineage; Balkano-Carpathian population includes birds from Romania and Bulgaria; Central East Europe population includes birds from Luxembourg, Germany, Czech Republic and Hungary belonging to the East European lineage.
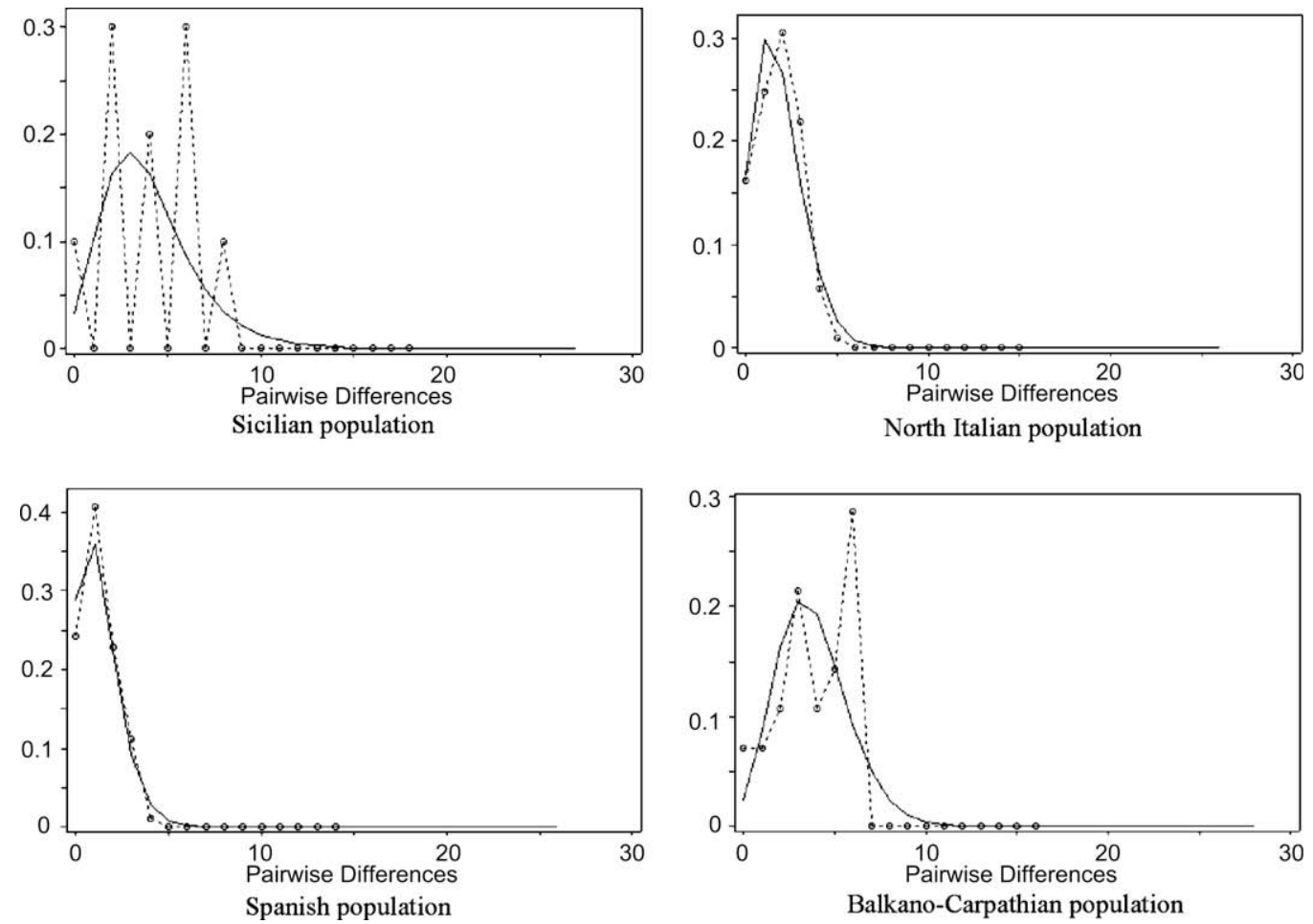

Fig. 3. Mismatch distribution analysis for mtDNA haplotypes from Sicilian, Northern Italian, Spanish and Balkano-Carpathian populations.

ity. The population expansion of Northern Italy and Northern Spain is also confirmed by the Fu's Fs tests (results not shown).

At the lineages level, mismatch distribution analyses conducted on the West European, East European, North East European and Moroccan lineages suggest a signal of recent expansion for these lineages (see Appendix 2). The low number of Caucasian, Asian and Corsican samples did not allow the use of such statistical tests for these groups.

\subsection{Divergence time}

Table 4 shows mean net distances within and between lineages, and divergence times between these lineages. Due to their isolation and to the genetic distances which separate them from the others lineages (see Fig. 2), the Corsican and the Asiatic individuals were considered as distinct lineages for the calculation of divergence times. Taking into account the correction for ancestral mtDNA polymorphism, the mean $\mathrm{K}_{2} \mathrm{P}$ distance between $C$. cinclus and C. pallasii is equal to $8.86 \%$. This value would correspond to a rate of $3.5 \% \mathrm{~K}_{2} \mathrm{P}$ distance per million years for our combined gene dataset. As a consequence, a chronology of separations between the different lineages could be proposed: (i) separation between the Asian lineage and the other lineages, possibly around 240280,000 years; (ii) separation between the East European and the West European lineage, around 120,000 years; (iii) these last two lineages separated from the other ones (North-East European, Moroccan, Caucasian and Corsican lineages) around 80-95,000 years ago; (iv) finally, the North-East European, Moroccan, Caucasian and Corsican lineages would have been the last ones to separate from each other, around $39-54,000$ years. 
Table 4

Mean net distances expressed as $\% \mathrm{~K}_{2} \mathrm{P}$ within (diagonal) and between (lower part of the table) the main lineages of $C$. cinclus and between $C$. cinclus, $C$. mexicanus and $C$. pallasiiEstimated divergence times ( $10^{3}$ years) between these lineages (upper part, in shaded grey) $(\mathrm{n} / \mathrm{c}=$ not considered)

\begin{tabular}{|c|c|c|c|c|c|c|c|c|c|}
\hline & Western Europe & Eastern Europe & Northern Europe & Corsica & Caucasus & Morocco & Asia & C. mexicanus & C. pallasii \\
\hline Western Europe & 0.0005 & 121 & 88 & 87 & 95 & 82 & 282 & & \\
\hline Eastern Europe & 0.0042 & 0.0009 & 80 & 77 & 88 & 70 & 259 & & \\
\hline North-East Europe & 0.0031 & 0.0028 & 0.0008 & 46 & 44 & 41 & 248 & & \\
\hline Corsica & 0.0030 & 0.0027 & 0.0016 & $n / c$ & 54 & 39 & 240 & & \\
\hline Caucasus & 0.0033 & 0.0031 & 0.0015 & 0.0019 & 0.0005 & 49 & 251 & & \\
\hline Morocco & 0.0029 & 0.0024 & 0.0014 & 0.0013 & 0.0017 & 0.0005 & 247 & & \\
\hline Asia & 0.0098 & 0.0090 & 0.0087 & 0.0084 & 0.0088 & 0.0086 & 0.0034 & & \\
\hline C. mexicanus & 0.1032 & 0.1023 & 0.1028 & 0.1033 & 0.1033 & 0.1035 & 0.1036 & $\mathbf{n} / \mathbf{c}$ & \\
\hline C. pallasii & 0.0899 & 0.0891 & 0.0892 & 0.0891 & 0.0891 & 0.0893 & 0.0907 & 0.8567 & $n / c$ \\
\hline
\end{tabular}

Ringing recovery analysis indicates the generation time of the dipper to lie between 1 and 1.5 years. Assuming this and with $u=0.035$, expansion dates for the four Western Palearctic lineages where a signal of expansion was observed, are all posterior to the LGM, ranging respectively from 10,000 (West European lineage) to 15,700 years BP (East European lineage) for a generation time equal to 1.5 years, and from 6700 to 10,500 years BP if the generation time is equal to one year (Table 5).

\section{Discussion}

\subsection{Phylogeographic patterns}

Our results support some of the previous findings on dipper phylogeography (Lauga et al., 2005), i.e. a weak genetic differentiation between West European populations and the existence of geographically widespread haplotypes among these populations.

However, the larger geographic scale and DNA sequence dataset employed in our study clearly shows the existence of geographically well-distinct lineages within the Western Palearctic populations of dippers: (i) a Western European lineage, (ii) an Eastern European lineage, (iii) a North-East European lineage, (iv) a Moroccan lineage and (v) a Caucasian lineage. Furthermore, our dataset highlights the important genetic differentiation between European (and North African) and Asian populations, and the isolation of the Corsican individual within Western Europe.

This is the highest number of lineages ever observed for a bird species in this region. Indeed, most phylogeographic studies performed on European birds resulted in the definition of only one to a maximum of three lineages, or no clear phylogeographic structure for the Western Palearctic (Merilä et al., 1997; Pitra et al., 2000; Liukkonen-Anttila et al., 2002; Pavlova et al., 2003; Randi et al., 2003; Zink et al., 2003; Kvist et al., 2004; Qu et al., 2005). One possible exception could be the tawny owl (Brito, 2005).

Although the nucleotide diversity values observed for the dipper appear very low when compared to other taxa from the same geographical zone, such as micromammals (Michaux et al., 2005), these values are of the same order of magnitude as those observed for several other European bird species. The same is true for haplotype diversity values (see Qu et al., 2005).

Divergence times calculated between the different lineages appear to be rather recent, between the Middle and Late Pleistocene. Avise and Walker (1998) have already underlined the major influ-

\section{Table 5}

Expansion times $\left(t_{\mathrm{e}}\right)$ expressed in years for the different lineages and for a generation time equal to 1 or 1.5 years

\begin{tabular}{llc}
\hline Lineage & $t_{\mathrm{e}}$ (generation time $=1.5$ years $)$ & $t_{\mathrm{e}}$ (generation time $=1$ year) \\
\hline East Europe & 15,725 & 10,484 \\
West Europe & 10,008 & 6672 \\
North East Europe & 12,583 & 8389 \\
Morocco & 11,863 & 7909 \\
\hline
\end{tabular}

ence of Pleistocene conditions in initiating major phylogeographic separations within bird species, and in completing speciations that had been inaugurated earlier. Later studies have also confirmed this concept (Qu et al., 2005).

Although we have to be very careful in estimating the divergence date in our analyses, these estimates help to propose a possible scenario explaining this phylogeographic pattern:

1. The Eastern and Western Palearctic populations were separated at the end of Middle Pleistocene.

2. Later, European dipper populations would have been isolated in at least two distinct refuges during one of the last ice ages, maybe corresponding to the Riss period (around 120,000 years ago). These refuges likely correspond to the Iberian and/or the Italian Peninsulas and Central Europe and/or in the Balkans. This scenario was already observed for many other European species (Santucci et al., 1998; Taberlet et al., 1998; Liukkonen-Anttila et al., 2002; Michaux et al., 2005). The isolation of these populations led to the appearance of the Western and Eastern European dipper genetic lineages. The colonisation of Morocco and Corsica would have happened during the same glacial period, facilitated by a lower sea level (Lambeck et al., 2002).

3. Dippers living in the Western Palaearctic probably expanded northward and eastward during a following interglacial, maybe corresponding to the Eemian period (120-72,000 years BP). Later, the large plains existing, as today, in most of northern Europe (i.e. from Northern Belgium and Netherlands to Russia, but also in Central Hungary) would have acted as barriers for this species. Indeed, the lack of a suitable riverine network for dippers through these plains would have, in some way, limited the exchanges between Western European populations and those now isolated in Scandinavia, the Ural Mountains and the Near East-Caucasus regions. These barriers associated with the sedentary behaviour of the dippers and to the isolation by distance with Western European populations, would have led to the appearance of the North East European, as well as the Caucasus lineages.

\subsection{Glacial refuges}

Haplotype and nucleotide diversity values observed for the different European populations of dipper tend to suggest that the North Italian, Sicilian and Balkano-Carpathian regions could have played the role of major refuge zones for dippers during the LGM.

Mismatch distribution analyses conducted on the Sicilian and Balkano-Carpathian populations (Fig. 3) also suggest that these populations would have remained constant during the last ice age, further evoking the existence of some refuge areas for the dipper in these regions. Fu's Fs tests also support this hypothesis (results not shown). Such a hypothesis of a Sicilian and/or a 
Balkano-Carpathian refuge has already been proposed for several other species including birds (Santucci et al., 1998; Michaux et al., 1998, 2005; Carlsson, 2003; Randi et al., 2003; Brito, 2005; Deffontaine et al.,2005; Nieberding et al., 2005; Kotlik et al., 2006).

In spite of a limited sampling for the Caucasus region, our results strongly support the existence of a particular lineage in this region which is well separated from all the other populations. The existence of a refuge in the Caspian/Caucasian region has already been proposed for different European temperate species (Durand et al., 1999; Deffontaine et al., 2005), but it is difficult to be more precise about such a lineage without better sampling in this region and in the neighbouring areas.

Corsica and North Africa have also been suggested as refuge zones for different European bird species (Marshall and Baker, 1999; Griswold and Baker, 2002; Kvist et al., 2004). Moreover, these regions are also known for their numerous endemic species and subspecies (Pasquet, 1998; Thibault and Bonnacorsi, 1999; Prodon et al., 2002; Thévenot et al., 2003). Our results tend to support such a hypothesis for North Africa. The hypothesis of a distinct Corsican dipper lineage must, however, be treated with caution since we only analysed one individual from this region.

Finally, the existence of a North-East European lineage suggests a northern and/or eastern refuge for this lineage. Northern refuges have already been proposed for different bird species (Tiedemann et al., 2004; Ruokonen et al., 2005), and other taxa (Fedorov et al., 1999; Hewitt, 2004; Nieberding et al., 2004; Ruokonen et al., 2005).

Scandinavia was completely glaciated during the LGM (Hewitt, 1996) and, although dippers are capable of enduring very low temperatures, it is not very likely that they could have survived in Scandinavia during this period, due to a restricted access to food resources when streams were frozen. Another more likely possibility is that dippers from the North East European lineage survived in places located more Eastward, close to the Ural Mountains. Indeed, Northern Russia was not so affected by ice compared to its neighbouring Scandinavian region (Hewitt, 1996), and the Ural region has already been proposed as a refuge zone for other species (Carlsson, 2003; Hewitt, 2004; Deffontaine et al., 2005). However, given the limited sampling we have for these regions, it is possible to discard neither of these two hypotheses.

\subsection{Postglacial expansion}

As observed for expansion date estimations of many Palearctic and Nearctic birds species (Qu et al., 2005), recolonisation of the Western Palearctic by dippers seems to have started immediately after the last ice age, i.e. between 16,000 and 10,000 years BP.

\subsubsection{West European lineage}

The star-like topology observed on the network as well as the mismatch distribution analyses following a Poisson model suggest that the West European lineage probably recolonised Europe recently from a small number of animals surviving in a single refuge.

On the basis of our results, a plausible hypothesis is that the recolonization of the Western European region began from an Italian refuge: at the end of the last glaciation, Italian birds expanded westwards to France and the Iberian Peninsula, but also northwards to reach Britain, Ireland, Belgium, Germany, Switzerland, Czech Republic and Hungary, crossing and/or bypassing the Alps.

\subsubsection{East European lineage}

As for the West European lineage, mismatch distribution for the East European lineage suggests that the East European lineage probably expanded just after the last ice age. When temperatures increased at the beginning of the last interglacial, BalkanoCarpathian populations expanded North-Westwards, following the Carpathian mountains and bypassing the Hungarian plain to colonize Northern Hungary, Slovakia, the Czech Republic, Germany and Luxembourg. This lineage entered into contact with the Western European one in these last regions, where they form a very large contact zone extending from Luxembourg to Hungary.

\subsubsection{Other lineages}

It is impossible to propose a pattern of postglacial recolonisation, due to our limited sampling.

\section{Conclusions}

As already reported for many Palearctic bird species (Seutin et al., 1995; Zink et al., 2002a; Pavlova et al., 2003; Koopman et al., 2005), the lack of concordance we observed between the morphological races as described by Cramp (1988) and the genetic lineages as defined by our results clearly raise the question of the validity for some of these subspecies, a fact that had already been quoted by Tyler and Ormerod (1994). Several recent examples propose that extensive morphological or behavioural differentiation can evolve rapidly in birds with little or no genetic differentiation (Zink and Dittmann, 1993; Ödeen and Björklund, 2003). This results from a rapid local adaptation to fluctuating resources (Questiau et al., 1999) and/or to sexual selection (Ödeen and Björklund, 2003). Therefore, this study highlights the necessity to reconsider the status of the different European subspecies and the relevance of the characters employed to discriminate these subspecies.

Above all, this study gives evidence of the impact of glacial periods on the genetic structure of a temperate species. However, in contrast to many other phylogeographic studies performed on birds and for the first time in Europe, our study also demonstrates the impact of interglacial periods. These gave rise to probably the highest number of different refuges ever observed in Europe for a single vertebrate species, and led to very complex phylogeographic patterns for the dipper within its Western Palearctic breeding range, with the determination of several geographically well distinct genetic lineages.

\section{Acknowledgments}

We are very grateful to Jiri and Susana Pokorny, Robert Horvath, Pat Smiddy, Ivelin Ivanov, Borja Palacios, Alberto Juanjo, Alonso Roves, José Enrique Granados, Jose Manuel de la Riva, Vicente Lopez Alcazar, Dr. Miriam Hernandez, Dr. Luca Giraudo, Dr. ssa Patrizia Rossi, Dr. Giuseppe Canavese, Dr. Johan Hegelbach, Edmund Racinskis, Edgars Dzenis, Oskars Keiss, Aigars Kalvans, Olav Overvoll, Vasil Ananian, Alexander Kaizer, Patric Lorge, Dr. Sharon Birks, Dr. D.M. Bryant, Dr. Jacques Franchimont, and Marton Kelemen for their help in collecting samples. We are also grateful to Dr. Caroline Nieberding, Prof. Steve Ormerod, Dr. Gary Voelker, Dr. Dorit Liebers and Dr. Ian Robbins for their help and suggestions during the different stages of this work.

\section{Appendix A. Supplementary data}

Supplementary data associated with this article can be found, in the online version, at doi:10.1016/j.ympev.2008.07.025.

\section{References}

Arctander, P., 1988. Comparative studies of avian DNA by restriction fragment length polymorphism analysis: Convenient procedures based on blood samples from live birds. J. Ornith. 129, 205-216.

Avise, J.C., Walker, C., 1998. Pleistocene phylogeographic effects on avian populations and the speciation process. Proc. R. Soc. Lond. B265, 457-463.

Avise, J.C., 2000. Phylogeography: The History and Formation of Species. Harvard Univ. Press, Cambridge, Massachusetts. 
Bandelt, H.J., Forster, P., Röhl, A., 1999. Median-joining networks for inferring intraspecific phylogenies. Mol. Biol. Evol. 16, 37-48.

Bennett, K.D., Tzedakis, P.C., Willis, K.J., 1991. Quaternary refugia of north European trees. J. Biogeogr. 18, 103-115.

Blondel, J., 1997. The evolution and history of European Bird fauna. In: Hagemeijer, W.J.M., Blair, M.J. (Eds.), The EDCC Atlas of European Breeding Birds. Poyser, London.

Bochenski, Z., 1997. List of European fossil bird species. Acta Zoolog. Cracov. 40 (2), 293-333.

Brito, P.H., 2005. The influence of Pleistocene glacial refugia on tawny owl genetic diversity and phylogeography in Western Europe. Mol. Ecol. 14, 3077-3094.

Carlsson, M., 2003. Phylogeography of the Adder, Vipera berus comprehensive summaries of Uppsala dissertations from the Faculty of Science and Technology. Acta Universitatis Upsaliensis 849, 34.

Clement, M., Posada, D., Crandall, K.A., 2000. TCS: a computer program to estimate gene genealogies. Mol. Ecol. 9, 1657-1659.

Comes, H.P., Kadereit, J.W., 1998. The effect of Quaternary climatic changes on plant distribution and evolution. Trends Plant Sci. 3 (11), 432-438.

Cramp, S.(Ed.), 1988. Handbook of the Birds of Europe, the Middle-East and North Africa, The Birds of the Western Palearctic, Volume V: Tyrant Flycatchers to Thrashes, Oxford Univ Press, Oxford, pp. 509-524.

Crochet, P.A., Bonhomme, F., Lebreton, J.D., 2000. Molecular phylogeny and plumage evolution in gulls (Larini). J. Evol. Biol. 13, 47-57.

D'Amico, F., Hémery, G., 2007. Time-activity budgets and energetics of the annual cycle of Dippers Cinclus cinclus in upland streams are dictated by temporal variability of river flow. Comp. Biochem. Physiol. 148, 811820 .

Deffontaine, V., Libois, R., Kotlík, P., et al., 2005. Beyond the Mediterranean peninsulas: evidence of central European glacial refugia for a temperate forest mammal species, the bank vole (Clethrionomys glareolus). Mol. Ecol. 14, 17271739.

Durand, J.D., Persat, H., Bouvet, Y., 1999. Phylogeography and postglacial dispersion of the chub (Leuciscus cephalus) in Europe. Mol. Ecol. 8, 989-997.

Edwards, S.V., Beerli, P., 2000. Perspective: gene divergence, population divergence and the variance in coalescence time in phylogeographic studies. Evolution 54, 1839-1854.

Fedorov, V., Goropashnaya, A., Jarrell, G.H., Fredga, K., 1999. Phylogeographic structure and mitochondrial DNA variation in true lemmings (Lemmus) from the Eurasian Arctic. Biol. J. Linn. Soc. 66, 357-371.

Felsenstein, J., 1981. Evolutionary tree from DNA sequences: a maximum likelihood approach. J. Mol. Evol. 17, 368-376.

Felsenstein, J., 1985. Confidence limits on phylogenies: an approach using the bootstrap. Evolution 39, 783-791.

Fitch, W.M., 1971. Towards defining the course of evolution: minimum change for a specific tree topology. Syst. Zoolog. 20, 406-416.

Fu, Y.X., 1997. Statistical tests of neutrality of mutations against population growth, hitchhiking and background selection. Genetics 147, 915-925

Gay, L., Defos Du Rau, P., Mondain-Monval, J.Y., Crochet, P.A., 2004. Phylogeography of a game species: the red-crested pochard (Netta rufina) and consequences for its management. Mol. Ecol. 13, 1035-1045.

Griswold, C.K., Baker, A.J., 2002. Time to the most recent common ancestor and divergence times of populations of common chaffinches (Fringilla coelebs) in Europe and North Africa: insights into the Pleistocene refugia and current levels of migration. Evolution 56 (1), 143-153.

Gu, X., Fu, Y.X., Li, W.H., 1995. Maximum likelihood estimation of the heterogeneity of substitution rate among nucleotide sites. Mol. Biol. Evol. $12,546-557$.

Guindon, S., Gascuel, O., 2003. A simple, fast, and accurate algorithm to estimate large phylogenies by maximum likelihood. Syst. Biol. 52, 696-704.

Hackett, S.J., 1996. Molecular phylogenetics and biogeography of Tanagers in the genus Ramphocelus (Aves). Mol. Phyl. Evol. 5, 368-382.

Hagemeijer, W.J.M., Blair, M.J., 1997. The EBC Atlas of European Breeding Birds Their Distribution and Abundance. T\&AD Poyser, London.

Hasegawa, M., Kishino, H., Yano, T., 1985. Dating of the human-ape splitting by a molecular clock of mitochondrial DNA. J. Mol. Evol. 21, 160-174.

Helm-Bychowski, K., Cracraft, J., 1993. Recovering phylogenetic signal from DNA sequences: Relationships within the corvine assemblage (Class Aves) as inferred from complete sequences of the mitochondrial DNA cytochrome $b$ gene. Mol. Biol. Evol. 10, 1196-1214

Hewitt, G.M., 1996. Some genetics consequences of ice ages, and their role in divergence and speciation. Biol. J. Linn. Soc. 58, 247-276.

Hewitt, G.M., 2004. The structure of biodiversity-insights from molecular phylogeography. Front. Zoolog. I. 4, 1-16.

Ho, S.Y.W., Phillips, M.J., Cooper, A., Drummond, A.J., 2005. Time dependency of molecular rate estimates and systematic overestimation of recent divergence times. Mol. Biol. Evol. 22 (7), 1561-1568.

Johnson, K.P., Sorenson, M.D., 1998. Comparing molecular evolution in two mitochondrial protein coding genes (cytochrome $b$ and ND2) in the dabbling ducks (Tribe: Anatini). Mol. Phyl. Evol. 10 (1), 82-94.

Kidd, M.G., Friesen, V.L., 1998. Analysis of mechanisms of microevolutionary change in Cepphus guillemots using patterns of control region variation. Evolution 52, 1158-1168.

Kocher, T.D., Thomas, W.K., Meyer, A., et al., 1989. Dynamics of mitochondrial DNA evolution in animals: amplification and sequencing with conserved primers. Proc. Natl. Acad. Sci. USA 86, 6196-6200.
Koopman, M.E., McDonald, D.B., Hayward, G.D., et al., 2005. Genetic similarity among Eurasian subspecies of boreal owls Aegolius funereus. J. Avian Biol. 36, 179-183.

Kotlik, P., Deffontaine, V., Mascheretti, S., et al., 2006. A northern glacial refugium for Bank voles (Clethrionomys glareolus). Proc. Natl. Acad. Sci. USA 103, 14860-14864.

Kumar, S., Tamura, K., Jakobsen, I.B.M., Nei, M., 2001. MEGA2: molecular evolutionary genetics analysis software. Bioinformatics 17, 1244-1245.

Kvist, L., Viiri, K., Dias, P.C., Rytkönen, S., Orell, M., 2004. Glacial history and colonization of Europe by the blue tit Parus caeruleus. J. Avian Biol. 35, 352359.

Lambeck, K., Esat, T.M., Potter, E.K., 2002. Links between climate and sea levels for the past three million years. Nature 419, 199-206.

Lauga, B., Cagnon, C., D’Amico, F., Karama, S., Mouchès, C., 2005. Phylogeogaphy of the white-throated dipper Cinclus cinclus in Europe. J. Ornith. 146, 257-262.

Liebers, D., Helbig, A.J., De Knijff, P., 2001. Genetic differentiation and phylogeography of gulls in the Larus cachinnans-fuscus group (Aves: Charadriiformes). Mol. Ecol. 10, 2447-2462.

Liukkonen-Anttila, T., Uimaniemi, L., Orell, M., Lumme, J., 2002. Mitochondrial DNA variation and the phylogeography of the grey partridge (Perdix perdix) in Europe: from Pleistocene history to present day populations. J. Evol. Biol. 15, 971-982.

Marshall, H.D., Baker, A.J., 1999. Colonisation history of Atlantic island common chaffinches (Fringilla coelebs) revealed by mitochondrial DNA. Mol. Phyl. Evol. 11 (2), 201-212.

Merilä, J., Björklund, M., Baker, A.J., 1997. Historical demography and present day population structure of the greenfinch Carduelis chloris-an analysis of mtDNA control-region sequences. Evolution 51 (3), 946-956.

Michaux, J., Sarà, M., Libois, R., Matagne, R., 1998. Is the wood mouse (Apodemus sylvaticus) of Sicily a distinct species? Belg. J. Zoolog. 128, 211-214.

Michaux, J.R., Libois, R.M., Filippucci, M.G., 2005. So close and so different. Comparative phylogeography of two closely related rodents species (Apodemus flavicollis and A. sylvaticus) in the Western Palearctic region. Heredity 94, 52-63.

Moum, T., Arnason, A., 2001. Genetic diversity and population history of two related seabird species based on mitochondrial DNA control region sequences. Mol. Ecol. 10, 2463-2477.

Mourer-Chauviré, C., 1995. Dynamics of the avifauna during the Paleogene and the early Neogene of France. Settling of the recent fauna. Acta Zoolog. Cracov. 38 (3), 325-342.

Nei, M., 1987. Molecular Evolutionary Genetics. Columbia University Press, New York.

Newton, I., 1998. Population Limitation in Birds. Academic Press ltd, London.

Nieberding, C., Morand, S., Michaux, J.R., 2004. A parasite reveals cryptic phylogeographic history of its host. Proc. R. Soc. Lond. B 271, 2559-2568.

Nieberding, C., Libois, R., Douady, C.J., Morand, S., Michaux, J.R., 2005. Phylogeography of a nematode (Heligmosomoides polygyrus) in the western Palearctic region: persistence of northern cryptic populations during ice ages? Mol. Ecol. 14, 765-779.

Ödeen, A., Björklund, M., 2003. Dynamics in the evolution of sexual traits: losses and gains, radiation and convergence in yellow wagtails (Motacilla flava). Mol. Ecol. 12, 2113-2130.

O'Halloran, J., Smiddy, P., O'Mahony, B., 2000. Movements of Dippers Cinclus cinclus in southwest Ireland. Ringing and Migration 20, 147-151.

Pasquet, E., 1998. Phylogeny of the nuthatches of the Sitta canadensis group and its evolutionary and biogeographic implications. Ibis 140, 150-156.

Pasquet, E., Cibois, A., Baillon, F., Erard, C., 1999. Relationships between the antthrushes Neocossyphus and the flycatcher-thrushes Stizorhina, and their position relative to Myadestes, Entomodestes and some other Turdidae (Passeriformes). J Zoolog Syst. Evol. Res. 37, 177-183.

Pavlova, A., Zink, R.M., Drovetski, S.V., Red'Kin, Y., Rohwer, S., 2003. Phylogeographic patterns in Motacilla flava and Motacilla citreola: species limits and population history. The Auk 120 (3), 744-758.

Philippe, H., 1993. MUST: a computer package of management utilities for sequences and trees. Nucleic Acids Res. 21, 5264-5272.

Pitra, C., Lieckfeldt, D., Alonso, J.C., 2000. Population subdivision in Europe's great bustard inferred from mitochondrial and nuclear DNA sequence variation. Mol. Ecol. 9, 1165-1170.

Posada, D., Crandall, K.A., 1998. MODELTEST: testing the model of DNA substitution. Bioinformatics 14, 817-818.

Prodon, R., Thibault, J.C., Dejaifve, P.A., 2002. Expansion vs. compression of bird altitudinal ranges on a Mediterranean island. Ecology 83, 1294-1306.

Qu, Y.H., Ericson, P.G.P., Lei, F.M., Li, S.H., 2005. Postglacial colonization of the Tibetan plateau inferred from the matrilineal genetic structure of the endemic red-necked snow finch, Pyrgilauda ruficollis. Mol. Ecol. 14, 1767-1781.

Questiau, S., Gielly, L., Clouet, M., Taberlet, P., 1999. Phylogeographical evidence of gene flow among common crossbill (Loxia curvirostra, aves, fringillidae) populations at the continental level. Heredity 83, 196-205.

Randi, E., Tabarroni, C., Rimondi, S., Lucchini, V., Sfougaris, A., 2003. Phylogeography of the rock partridge (Alectoris graeca). Mol. Ecol. 12, 2201-2214.

Rogers, A.R., Harpending, H., 1992. Population growth makes waves in the distribution of pairwise genetic differences. Mol. Biol. Evol. 9, 552-569.

Rozas, J., Sánchez-DelBarrio, J.C., Messeguer, X., Rozas, R., 2003. dnaSP, DNA polymorphism analyses by the coalescent and other methods. Bioinformatics 19, 2496-2497.

Ruokonen, M., Aarvak, T., Madsen, J., 2005. Colonization history of the high-arctic pink-footed goose Anser brachyrhynchus. Mol. Ecol. 14, 171-178. 
Saitou, N., Nei, M., 1987. The neighbor-joining methods: a new method for reconstructing phylogenetics trees. Mol. Biol. Evol. 4, 406-425.

Santucci, F., Emerson, B.C., Hewitt, G.M., 1998. Mitochondrial DNA phylogeography of European hedgehogs. Mol. Ecol. 7, 1163-1172.

Schneider, S., Roessli, D., Excoffier, L., 2000. Arlequin version 2.0: a software for population genetics data analysis? Genetics and Biometry Laboratory, University of Geneva.

Seutin, G., Ratcliffe, L.M., Boag, P.T., 1995. Mitochondrial DNA homogeneity in the phenotypically diverse redpoll finch complex (Aves: Carduelinae: Carduelis flammea-hornemanni). Evolution 49, 962-973.

Swofford, D.L., 2000. PAUP*: phylogenetic analysis using parsimony ( $*$ and other methods). v.4.0. Sinauer Associates, Sunderlands, MA.

Taberlet, P., Fumagalli, L., Wust-Saucy, A.G., Cosson, J.F., 1998. Comparative phylogeography and postglacial colonisation routes in Europe. Mol. Ecol. 7, 453-464.

Tajima, F., 1993. Measurement of DNA polymorphism. In: Takahata, N., Clark, AG (Eds.), Mechanisms of Molecular Evolution. Sinauer Associates, Sunderland Massachussetts, pp. 37-59.

Thévenot, M., Vernon, R., Bergier, P., 2003. The Birds of Morocco. British Ornithologists' Union, 594.

Thibault, J.C., Bonnacorsi, G., 1999. The birds of Corsica. British Ornithologists' Union Checklist 17, 172.

Tiedemann, R., Paulus, K.B., Scheer, M., et al., 2004. Mitochondrial DNA and microsatellite variation in the eider duck (Somateria mollissima) indicate stepwise postglacial colonization of Europe and limited current long-distance dispersal. Mol. Ecol. 13, 1481-1494.
Tyler, S., Ormerod, S., 1994. The Dippers. T\&AD Poyser, London. pp. 225.

Voelker, G., 2002. Molecular phylogenetics and the historical biogeography of dippers (Cinclus). Ibis 144, 577-584.

Webb, T., Bartlein, P.J., 1992. Global changes during the last 3 million years: climatic controls and biotic responses. Annu. Rev. Ecol. Syst. 23 141-173.

Yang, Z., 1993. Maximum likelihood estimation of phylogeny from DNA sequences when substitution rates differ over sites. Mol. Biol. Evol. 10 1396-1402.

Yang, Z., 1996. Among-site rate variation and its impact on phylogenetic analyses. Trends Ecol. Evol. 11, 367-371.

Zink, R.M., 1997. Phylogeographic studies of North American birds. In: Mindell, D.P. (Ed.), Avian Molecular Evolution and Systematics. Academic Press, San Diego, CA, pp. 301-324.

Zink, R.M., Dittmann, D.L., 1993. Gene flow, refugia, and the evolution of geographic variation in the Song Sparrow (Melospiza melodia). Evolution 47, 717-729.

Zink, R.M., Drovetski, S.V., Rohwer, S., 2002a. Phylogeographic patterns in the great spotted woodpecker Dendrocops major across Eurasia. J. Avian Biol. 33, 175178.

Zink, R., Rohwer, S., Drovetski, S., Blackwell-Rago, R., Farrell, S.L., 2002b. Holarctic phylogeography and species limits of three-toed woodpeckers. The Condor 104 , 167-170.

Zink, R.M., Drovetski, S.V., Questiau, S., Fadeev, I.V., 2003. Recent evolutionary history of the bluethroat (Luscinia svecica) across Eurasia. Mol. Ecol. 12, 30693075. 